\title{
Perbandingan Pola Kuman dan Analisis Kualitas Bakteriologis pada Kolam Renang Jenis Learner Pool dan Standard Pool di Purwokerto
}

\section{Comparison of Microbial Pattern and Bacteriological Quality Analysis on Learner and Standard Swimming Pool in Purwokerto}

\author{
Raden Maghfira Kurnia Kusuma ${ }^{1}$, Prima Maharani Putri ${ }^{1}$, Andi Muh. Maulana ${ }^{1}$
}

1)Program Studi Pendidikan Dokter Fakultas Kedokteran, Universitas Muhammadiyah Purwokerto

\begin{abstract}
Abstrak
Latar Belakang: Infeksi adalah penyakit yang disebabkan oleh agen infeksius tertentu yang dapat menyerang semua sistem tubuh manusia. Banyaknya kemunculan kembali re-emerging diseases dan new emerging diseases menjadi masalah kesehatan di Indonesia yang menjadikan penyakit menular memiliki kecenderungan mengalami peningkatan. Tempat umum seperti kolam renang dapat menjadi salah satu sumber dari transmisi agen infeksius dengan rute kontak langsung. Guideline WHO tahun 2006, telah mengatur indeks kebersihan dengan analisis kualitas bakteriologis dilihat dari pola kuman dan tinjauan kebersihan. Penelitian ini bertujuan mengetahui perbedaan pola kuman dan analisis kualitas bakteriologis pada kolam renang jenis learner pool dan standard pool di Purwokerto.
\end{abstract}

Metode: Penelitian analitik observasional dengan pendekatan cross-sectional, melibatkan 4 sampel dengan total sampling, analisa data menggunakan Uji Fisher.

Hasil: Hasil analisis kualitas bakteriologis pada kolam renang learner pool dan standard pool di keempat tempat yang diteliti adalah baik dan cukup serta tidak terdapat perbedaan yang signifikan $(p=0,757)$.

Kesimpulan: Tidak terdapat perbedaan yang signifikan pola kuman dan analisis kualitas bakteriologis pada kolam renang learner pool dan standard pool di Purwokerto

Kata Kunci : Infeksi, pola kuman, analisis kualitas bakteriologis, kolam renang 


\begin{abstract}
Background: Infectious diseases are caused by a infectious agent that is able to attack all human body systems. Large number of re-emerging diseases and new emerging diseases have became a health problem in Indonesia, as a result, the trend increases. Some area of public places such as swimming pools is one of the most frequent sources of transmission of infectious pathogens with direct contact. The WHO Guideline in 2006, has established a hygiene index with bacteriological quality analyzes seen from the microbial pattern and pool-related hygiene reviews. The aim to obserb the diversity of microbial pattern and bacteriological quality analysis at learner and standard swimming pools in Purwokerto.
\end{abstract}

Method: The observational analytical research is conducted with a cross-sectional approach, involving 4 samples with total sampling, while data analysis uses a Fisher Test.

Results: The results of bacteriological quality analysis in both learner and standard swimming pools in all four sites studied were good and sufficient based on WHO Guideline in 2006 and that there was no significant difference $(p=0,757)$.

Conclusion: There is no significant difference of microbial pattern and bacteriological quality analysis at both learner and standard swimming pools in Purwokerto

Keywords: Infection, microbial pattern, bacteriological quality analysis, swimming pool

\section{PENDAHULUAN}

Penyakit infeksi adalah penyakit yang disebabkan oleh suatu agen infeksius. Banyaknya kemunculan kembali penyakit menular lama (re-emerging diseases) dan penyakit menular baru (new emerging diseases) menjadi masalah kesehatan di Indonesia yang menjadikan penyakit menular memiliki kecenderungan mengalami peningkatan dari tahun ke tahun. ${ }^{1}$

Penyebaran atau rute transmisi penyakit infeksi ini dapat melalui kontak langsung, kontak tidak langsung, droplet, aerosol, vektor dan cairan tubuh. ${ }^{2}$ Beberapa tempat umum seperti kolam renang juga dapat menjadi salah satu sumber dari transmisi patogen infeksius cara yang paling sering dengan kontak langsung. ${ }^{3}$

Kolam renang merupakan tempat umum yang digunakan oleh masyarakat untuk rekreasi, olahraga atau sebagai tempat rehabilitasi yang sudah diatur kebersihannya. ${ }^{4}$ Beberapa jenis kolam renang berdasarkan ukuran yang banyak ditemui di Purwokerto seperti jenis learner pool dan standard pool yang banyak digunakan oleh masyarakat Purwokerto untuk sarana olahraga menjadikan Purwokerto memiliki banyak atlet pada cabang olah raga air.

Penelitian Bello pada tahun 2012 telah menganalisis pola kuman pada kolam renang dan ditemukan beberapa bakteri seperti Enterococcus faecalis, Clostridium perfringens, Bacillus cereus, Escherichia coli, Pseudomonas aeruginosa, Staphylococcus aureus, Staphylococcus epidermidis dan Proteus vulgaris yang dapat meningkatkan faktor risiko terkena penyakit infeksi gastrointestinal dan integumen bagi pengguna sekitar 50\%.6

Guideline WHO tahun 2006, telah mengatur indeks kebersihan dengan analisis 
kualitas bakteriologis dilihat dari pola kuman dan tinjauan kebersihan yang berhubungan dengan kolam renang. Oleh karena itu, berdasarkan paparan di atas, maka peneliti berkeinginan untuk menelaah tentang perbandingan pola kuman dan analisis kualitas bakteriologis pada kolam renang jenis learner pool dan standard pool di Purwokerto. ${ }^{7}$

\section{METODE}

Penelitian ini merupakan jenis penelitian non desain khusus observasional analitik dengan rancangan penelitian cross sectional. Tempat pelaksanaan penelitian di kolam renang A, B, C dan D. Dengan ukuran kolam renang learner pool adalah 7-20 m dengan kedalaman 0,6 m. Sedangkan untuk standard pool memiliki ukuran 17-25 m dengan kedalaman 1,8 m. Sampel yang diambil berupa air sebanyak $250 \mathrm{ml}$ dan kedalaman pengambilan $20 \mathrm{~mm}$ dari permukaan air. Pengambilan sampel dilakukan pada bulan November dan Desember pada saat pengguna kolam renang maksimum. Sampel diambil pada dua titik sampel yaitu pada pinggir dan tengah kolam renang. Masing-masing sampel ditanam pada Blood Agar, Nutrient Agar dan Mac Conkey Agar kemudian diinkubasi selama 24 jam, dihitung jumlah koloni yang terbentuk, diwarnai menggunakan pewarnaan gram dan uji biokimia. Bakteri gram positif dilakukan uji biokimia berupa katalase dan koagulase. Bakteri gram negatif dilakukan uji biokimia berupa IMViC (Indole, Metbyl red, Voges proskaner, Citrate) TSIA dan motilitas. Data untuk mengetahui perbandingan pola kuman dan analisis kualitas bakteriologis pada kedua jenis kolam renang di analisis menggunakan uji Fisher untuk mengetahui perbandingan analisis kualitas bakteriologis dari kedua jenis kolam renang.

\section{HASIL PENELITIAN}

Hasil analisis (Tabel 1) menunjukkan kolam renang yang memiliki kualitas bakteriologis baik pada jenis learner pool dan standard pool adalah kolam renang D. Kolam renang yang memiliki kualitas bakteriologis cukup pada jenis learner pool dan standard pool adalah kolam renang $\mathrm{C}$.

Tabel 1. Perbandingan pola kuman dan analisis kualitas bakteriologis pada kolam renang jenis learner pool dan standard pool di Purwokerto

\begin{tabular}{llll}
\hline Kolam & \multicolumn{2}{c}{ Kualitas } & P value \\
renang & \multicolumn{2}{c}{ bakteriologis } & \\
\cline { 2 - 3 } & $\begin{array}{l}\text { Learner } \\
\text { pool }\end{array}$ & $\begin{array}{l}\text { Standard } \\
\text { pool }\end{array}$ & \\
\hline A & Baik & Cukup & \\
B & Cukup & Baik & 0,757 \\
C & Cukup & Cukup & \\
D & Baik & Baik & \\
\hline
\end{tabular}

Jumlah bakteri pada learner pool berdasarkan pewarnaan gram (Gambar 1.), didapatkan bahwa jumlah total bakteri pada learner pool adalah sebanyak 49 dengan jumlah 
paling banyak yaitu gram negatif sebanyak 31 $(63,27 \%)$ dan jumlah gram positif sebanyak 18 $(36,73 \%)$.

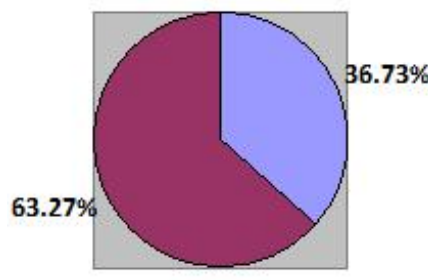

$\square$ gram positif

$\square$ gram negatif

Gambar 1. Jumlah bakteri pada learner pool berdasarkan pewarnaan gram

Jumlah bakteri pada standard pool (Gambar 2.), berdasarkan pewarnaan gram adalah sebanyak 19 dengan jumlah paling banyak yaitu gram negatif sebanyak $11(57,89 \%)$ dan jumlah gram positif sebanyak $8(42,11 \%)$.

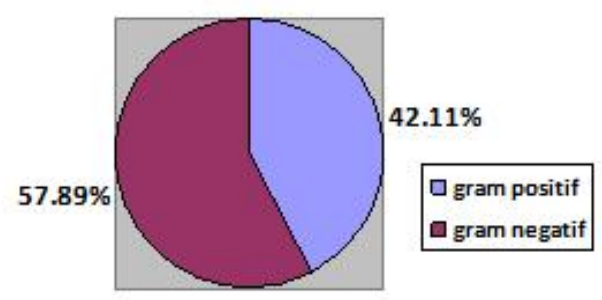

\section{Gambar 2. Jumlah bakteri pada standard pool berdasarkan pewarnaan gram}

Hasil pemeriksaan spesies atau genus bakteri (Tabel 2) menunjukkan bahwa Pseudomonas sp. merupakan jenis bakteri terbanyak pada kolam renang learner pool yaitu sebanyak 21 koloni (43,75\%) dan jenis bakteri paling sedikit adalah Klebsiella pneumonia dan Vibrio vulnifucus dengan jumlah 1 koloni (2,08 $\%$ ). Jenis bakteri terbanyak pada kolam renang standard pool adalah Pseudomonas sp. yaitu sebanyak 7 (35\%) dan yang paling sedikit adalah E. coli, Enterobacter intermedius dan Klebsiella pneumonia dengan jumlah 1 koloni (5 $\%)$.

Analisis data untuk mengetahui perbandingan pola kuman dan analisis kualitas bakteriologis pada kolam renang jenis learner pool dan standard pool di Purwokerto ini menggunakan uji Fisher dengan nilai P 0,757 $(\mathrm{P}>0,05)$. Hal ini menunjukkan bahwa tidak terdapat perbedaan pola kuman dan analisis kualitas bakteriologis pada kolam renang learner pool dan standard pool di Purwokerto 
Tabel 2. s bakteri pada kolam renang jenis learner pool dan standard pool di Purwokerto

\begin{tabular}{|c|c|c|c|c|}
\hline No. & Jenis bakteri & & Learner pool & Standard pool \\
\hline \multirow[t]{2}{*}{1.} & (Coagulase & Negative & $12(25 \%)$ & $6(30 \%)$ \\
\hline & Staphylococcus) & & & \\
\hline 2. & Staphylococcus aureus & & $6(12,5 \%)$ & $2(10 \%)$ \\
\hline 3. & Pseudomonas sp. & & $21(43,75 \%)$ & $7(35 \%)$ \\
\hline 4. & Eschericia coli & & $3(6,25 \%)$ & $1(5 \%)$ \\
\hline 5. & Enterobacter intermedius & & $2(4,16 \%)$ & $1(5 \%)$ \\
\hline 6. & Serratia fonticola & & $2(4,16 \%)$ & - \\
\hline 7. & Klebsiella pneumonia & & $1(2,08 \%)$ & $1(5 \%)$ \\
\hline \multirow[t]{2}{*}{8.} & Vibrio vulnificus & & $1(2,08 \%)$ & $2(10 \%)$ \\
\hline & Total & & $48(100 \%)$ & $20(100 \%)$ \\
\hline
\end{tabular}

\section{PEMBAHASAN}

Peraturan Menteri Kesehatan RI No. 416/Menkes/Per/IX/1990 tentang Syarat-syarat dan Pengawasan Kualitas Air telah menetapkan bahwa nilai maksimal CFU untuk kolam renang adalah $<200$, sehingga semua kolam renang yang di teliti oleh peneliti masih layak untuk digunakan. ${ }^{8}$ WHO mengklasifikasifikan untuk air yang berada pada kondisi low risk memiliki 1-10 cfu/100 ml, air dengan kondisi intermediate risk merupakan air yang mengandung 10-100 cfu/100 ml sampel. Air dengan total nilai 100$1000 \mathrm{cfu} / 100 \mathrm{ml}$ sampel merupakan high risk water.

Dari keempat kolam renang yang diteliti, kolam renang $\mathrm{D}$ menjadi kolam renang dengan kualitas bakteriologis baik di kedua jenis kolam renangnya. Dengan perawatan air metode tersier (menggunakan penyaringan mikro, UV dan pengendapan), kolam renang $\mathrm{D}$ termasuk kategori baik meskipun mempunyai jumlah CFU sebanyak 130 yang termasuk high risk water dan standard pool pada kolam renang ini dapat masuk menjadi kategori baik meskipun memiliki jumlah CFU sebanyak 159 yang termasuk bigh risk water.
Kolam renang $\mathrm{C}$ memiliki kualitas bakteriologis cukup dikedua jenis kolam renangnya. Dengan perawatan air menggunakan metode sekunder (pengendapan dan penyaringan), kolam renang $\mathrm{C}$ termasuk kategori cukup meskipun learner pool pada kolam renang C memiliki jumlah CFU 114 yang termasuk high risk water dan standard pool memiliki jumlah CFU 166 yang termasuk high risk, water juga.

Kategori kualitas bakteriologis pada kolam renang learner pool sebaiknya lebih baik bila dibandingkan dengan standard pool. ${ }^{7} \mathrm{Hal}$ ini sesuai dengan penelitian yang dilakukan oleh peneliti yaitu kolam renang standard pool tidak lebih baik dibandingkan dengan learner pool kecuali pada kolam renang $\mathrm{B}$.

Musim panas menjadi kontaminasi paling tinggi dapat disebabkan oleh tingginya temperatur yang membuat bakteri tumbuh di medium yang cocok sehingga akan lebih banyak tumbuh.9 Penelitian ini dilakukan pada bulan November dan Desember yang termasuk musim hujan sehingga dapat mempengaruhi jumlah CFU yang didapatkan. 
Setelah dilakukan penghitungan jumlah CFU, langkah selanjutnya adalah pewarnaan gram. Pewarnaan gram merupakan pewarnaan paling penting yang digunakan untuk menentukan jenis bakteri. Pewarna utama yang digunakan adalah kristal violet yang ditambahkan dengan iodin untuk membantu penempelannya. Titik penentuan pewarnaan gram terdapat pada dekolorisasi. Gram negatif dapat dilakukan dekolorisasi sehingga akan berwarna merah seperti safranin, namun gram positif tidak dapat dilakukan dekolorisasi sehingga akan berwarna ungu seperti kristal violet. Hal ini disebabkan karena adanya perbedaan struktur dinding sel antara gram positif dan gram negatif. Gram negatif memiliki dinding sel yang kaya akan lemak dan rendah peptidoglikan, begitu pula sebaliknya untuk gram positif. ${ }^{10}$

Peneliti melakukan uji biokimia setelah pewarnaan gram untuk menentukan genus atau spesies bakteri. Gram positif dilakukan dua uji yaitu uji katalase dan uji koagulase. Uji katalase dilakukan untuk mengetahui apakah bakteri memproduksi enzim katalase atau tidak. Dengan menggunakan $\mathrm{H}_{2} \mathrm{O}_{2} 3 \%$, bakteri yang memiliki enzim katalase akan memecahnya menjadi air dan oksigen sehingga akan terbentuk gelembung udara jika positif. ${ }^{11}$ Dilanjutkan dengan uji koagulase, bakteri yang memiliki enzim koagulase maka akan mengubah fibrinogen menjadi fibrin setelah diberi plasma. ${ }^{12}$

Keempat sampel kolam renang diambil dan dilakukan pewarnaan gram. Hasil pewarnaan gram menunjukkan terdapat gram positif dan lebih banyak didominasi oleh gram negatif. Gram negatif yang ditemukan dari penelitian kali ini adalah Pseudomonas sp., Eschericia coli, Enterobacter intermedius, Serratia fonticola, Klebsiella pneumoniae dan Vibrio vulnificus. Gram negatif yang paling banyak ditemukan pada learner pool dan standard pool adalah Pseudomonas sp. sedangkan untuk bakteri paling sedikit yang dapat ditemukan di learner pool dan standard pool adalah Klebsiella pneumonia.

Pseudomonas sp. dapat menyebabkan penyakit infeksi pada kulit dan telinga namun jarang menginfeksi pada orang yang sehat. Pseudomonas sp. terdapat di air karena beberapa hal seperti kontaminasi perenang, dari sumber air kolam renang tersebut ataupun dari daerah sekitar kolam yang masih basah. ${ }^{13}$ Bakteri berikutnya yang ditemukan adalah Eschericia coli. Bakteri tersebut mengindikasikan tidak berhasilnya penggunaan klorin dikarenakan Eschericia coli seharusnya tidak ada pada $100 \mathrm{ml}$ sampel air. Pada penelitian ini ditemukan Eschericia coli pada kedua jenis kolam renang di keempat tempat. Hal ini dapat dikarenakan dari pengguna kolam renang yang sudah terkontiminasi dengan bakteri tersebut

Bakteri gram positif yang ditemukan pada penelitian ini adalah Staphylococcus aureus dan CoNS (Coagulase Negative Staphylococcus). Staphylococcus aureus merupakan flora normal manusia yang terdapat di mukosa nasal, kulit dan pada feses orang sehat. Namun jika jumlah terlalu banyak, lingkungan pertumbuhan mendukung dan host memiliki imun yang rendah dapat menjadi patogen pada kulit, luka, mata, telinga dan saluran urin. CoNS juga merupakan flora normal pada kulit dan dapat menyebabkan infeksi nosocomial. ${ }^{14}$

Penelitian Osei-Adjei, menunjukkan adanya Klebsiella pneumoniae yang dapat diisolasi dari seluruh kolam yang ditelitinya. Klebsiella pneumoniae dapat ditemukan pada tanah, air, 
buah maupun sayuran yang ditransmisikan melalui droplet sehingga dapat menyebabkan infeksi pada saluran pernapasan. ${ }^{15}$

Kontaminasi pada kolam renang dapat dibagi menjadi dua yaitu secara fekal yang di dapat dari pengguna, binatang atau sumber air yang sudah terkontaminasi dan secara nonfekal yang didapat dari kulit manusia, sekresi dan angin. ${ }^{16}$

Penelitian ini memiliki beberapa keterbatasan seperti, tidak dapat mengontrol kontaminasi. Sampel diambil pada saat kontaminasi maksimum sehingga semakin banyak jenis bakteri yang dapat ditemukan. Kontaminasi juga didapat dari peneliti saat melakukan penelitian.

\section{SIMPULAN}

Tidak terdapat perbedaan pola kuman dan analisis kualitas bakteriologis pada kolam renang learner pool dan standard pool di Purwokerto.

\section{DAFTAR PUSTAKA}

1. Riskesdas, 2007 Riset Kesehatan Dasar. 2007. Jakarta: Badan Penelitian dan Pengembangan Kesehatan, Departemen Kesehatan, Republik Indonesia.

2. Miiller, M. \& Crispian, S. (2015) Infection and Control. In: Mosby's Text Book of Dental Nursing. 2nd edition. Elsevier. p. 90.

3. Karami, A., hossein Mahvi, A., Sharafi, K., Khosravi, T., Moradi, M., others, 2015. Comparing and evaluating microbial and physicochemical parameters of water quality in men's and women's public swimming pools in Kermanshah, Iran: A case study. International Journal of Environmental Health Engineering 4, 26.
4. Mokhtari M, Babaye A. (2012). Sanitary of House \&o Public Places. 1 th ed. Tehran, Iran: Sobhan Publication.

5. Sport England (2011) Swimming Pools. [Online]. 2011. Available from: https://www.sportengland.org/media/4565 / swimming-pools-design-2011-rev3.pdf.

6. Bello, O.O., Mabekoje, O.S., Egberongbe, H.O. and Bello, T.K. 2012. Microbial Qualities of Swimming Pools in Lagos, Nigeria. International Journal of Applied Science and Technology, 2, 89-96.

7. World Health Organization (WHO). 2006. Microbial Hazards. In: Guidelines for Safe Recreational Water Environments. Swimming Pools and Similar Environment, Volume 2, WHO Press, Geneva, 26-59 (Chapter 3).

8. Republik Indonesia. (2014). Peraturan Menteri Kesehatan RI No. 416/Menkes/Per/IX/1990 tentang Syaratsyarat dan Pengawasan Kualitas Air. Sekretariat Negara. Jakarta.

9. Rasti, S., Assadi, M.A., Iranshahi, L., Saffari, M., Gilasi, H.R., Pourbabaee, M., 2012. Assessment of Microbial Contamination and Physicochemical Condition of Public Swimming Pools in Kashan, Iran. Jundishapur Journal of Microbiology 5, 450-455. https://doi.org/10.5812/jim.2478

10. Leboffe, Michael J, \& Burton E., (2011). A Phatographic Atlas for the Microbiology Laboratory. USA: Morton Publshing.

11. Hemraj, V., Diksha, S. \& Avneet, G. (2013) A review on commonly used biochemical test for bacteria. Innovare Journal of Life Science. [Online] 1 (1), 1-7. Available from: http://innovareacademics.in/journals/index .php/ijls/article/viewFile/30/36.

12. Brooks, G.F., Butel, J.S., Ornston, L.N. (2013). Jawetr, Melnick \& Adelberg Medical Microbiology. McGraw-Hill Companies, Inc: United States.

13. Eze VC, Onwuakor CE \& Ikwuegbu AL (2015) Microbiological and Physicochemical Characteristics of Swimming Pool Water in Owerri, Imo State, Nigeria. Journal of Applied \& Environmental Microbiology. [Online] 3 (1), 6-10. Available from: doi:10.12691/jaem-3- 
1-2.

14. Becker, K., Heilmann, C., Peters, G., (2014). Coagulase-Negative Staphylococci. Clinical Microbiology Reviews 27, 870-926. https://doi.org/10.1128/CMR.00109-13.

15. Osei-Adjei, G., Sarpong, S.K., Laryea, E., Tagoe, E., others, 2014. Bacteriological quality assessment of swimming pools in the
Osu-Labadi Area, Accra. Journal of Natural Sciences Research 4, 126-129.

16. NSW (2013) Public Swimming Pool and Spa Pool Advisory Document. [Online]. 2013. Available from: http://www.health.nsw.gov.au/environmen t/Publications/swimming-pool-and-spaadvisory-doc.pdf. 